\title{
Candidacy Eligibility \\ Criteria and Party Unity
}

\section{Jochen Rehmert ${ }^{1}(\mathbb{D}$}

\begin{abstract}
Extant research suggests that candidate selection methods can be consequential for party unity in legislative voting. Yet thus far, only variations in the selectorate and the degree of centralization have been examined. This article argues that Candidacy Eligibility Criteria (CEC), too, have implications for party unity. I theorize that with stricter formal requirements, parties avoid adverse selection and ensure the nomination of committed candidates. By using roll-call vote data from 16 industrial democracies, candidate surveys and an original data set consisting of nearly 500 historical party constitutions, I show that parties demanding prior membership and nudging aspirants to maintain networks within the party tend to be more unified in parliamentary voting. Moreover, their candidates, too, express greater loyalty when compared with parties without formal CEC. Thus, this article contributes to the literatures on party unity and on candidate selection by showing how certain party rules, hitherto neglected, affect party unity.
\end{abstract}

\section{Keywords}

candidate selection, candidacy, eligibility criteria, party unity

\section{Introduction}

Party unity is essential for parliamentary democracy and most parties in parliamentary systems, indeed, exhibit highly unified voting records. Explanations

\footnotetext{
'Humboldt-Universität zu Berlin, Germany

\section{Corresponding Author:}

Jochen Rehmert, Humboldt-Universität zu Berlin, Institut für Sozialwissenschaften, Universitätsstraße 3b, I0II7 Berlin, Germany.

Email: jochen.rehmert.I@hu-berlin.de
} 
for variation in parliamentary voting range from systemic factors (e.g., Carey, 2009), over electoral incentives (e.g., Kam, 2009), to the sorting of like-minded citizens into parties at the individual level (e.g., Willumsen, 2017). In addition, previous research has identified that the way how parties select their candidates and who within the party wields power over candidates' (re-)nomination can be consequential for party unity (e.g., Bowler et al., 1999; Hazan \& Rahat, 2010; Rahat \& Hazan, 2001).

However, despite its central theoretical significance in explaining unified party behavior, empirical research examining the role of candidate selection methods (CSM) is still limited. Only a small number of recent studies aiming to explain voting unity has produced some empirical findings on the impact of CSM on party voting unity (Depauw \& Martin, 2008; Faas, 2003; Hix, 2004; Shomer, 2016, 2017). These studies assume that Members of Parliament (MPs) respond rationally to the incentive structure of parties' selection methods and understand observed party unity as the result of incentive-induced obedient behavior by re-(s)election seeking MPs.

To gain some leverage on the effect of CSM on party voting unity, these studies have modeled in one fashion or another the extent to which party leaders control access to the ballot. This usually has been measured by the exclusiveness of the selectorate (e.g., Faas, 2003; Shomer, 2016), the level at which selection takes place - that is, decentralized selection versus centralized selection (e.g., Depauw \& Martin, 2008; Hix, 2004; Shomer, 2016)—or by collapsing both dimensions together (e.g., Shomer, 2017). Empirically, centralization of candidate selection and the exclusiveness of the selectorate have been found to exert influence on party unity in line with expectations; more centralized selection is correlated with higher unity (Depauw \& Martin, 2008; Hix, 2004) and more exclusive selectorates are associated with more unified parties as well (Shomer, 2016), with a twisted result for members of the European Parliament though (Faas, 2003).

Yet, while previous studies have primarily looked at who selects, an equally important question is to ask who can be selected? In other words, who can formally present themselves as candidates at the time of nomination? Is candidacy open to all citizens or is it restricted to party members which might even have to sign pledges of loyalty, collect signatures or be affiliated with labor unions? The question is not merely about who can become the party's candidate, but more profoundly what type of personnel and applicants are wanted for or barred from standing as candidates according to formal party rules? How lenient or strict are parties in their nominations, what type of personnel is excluded from standing as a candidate and what consequences does this have for the unity of the party? As voters in most electoral systems face a "take it or leave it option" in the voting booth, 
these candidacy criteria set by parties have crucial implications for the makeup of the party-elect in parliament.

A telling example of the importance of candidate screening is provided by the Dutch List Pym Fortuyn (LPF). Founded only briefly before the 2002 Dutch general elections, the party was in a hurry to nominate candidates to exploit its advantageous standing in the electorate. Gaining eventually $17 \%$ of the seats, the LPF became pivotal in the coalition arithmetic and entered government as a junior partner to the Christian Democratic Appeal (CDA), besides the People's Party for Freedom and Democracy (VVD). Yet, the lack of formal and informal screening mechanisms led to the selection of a set of inexperienced and incoherent candidates, many of whom campaigned solely because they were friends of Fortuyn. The dismal performance and constant infighting among the party's ministers and MPs finally resulted in the premature termination of the coalition (de Lange \& Art, 2011, p. 1242). A few years later, Geert Wilders left the VVD and founded his Party for Freedom (PVV) with a similar ideological outlook as the LPF. One of the biggest differences between both parties, however, are the screening and vetting procedures employed when selecting candidates. In fact, Wilders personally vetted candidates and mentored MPs thoroughly in the beginning of the party building process and even imposed an admission stop on new party members (de Lange \& Art, 2011). Nowadays, the PVV is one of the most unified parties in the already highly cohesive Dutch parliament and many parties have institutionalized screening mechanisms in many formalized ways.

Yet, despite the fundamental significance of these party rules, extant research has neglected this "candidacy" dimension of candidate selection (see Hazan \& Rahat, 2010; Rahat \& Hazan, 2001). The empirical studies mentioned above have so far examined only one or two dimensions of selection, namely the dimension of the selectorate and the degree of centralization of selection. Overall, research on candidacy eligibility is scarce. Early studies, however, have already emphasized the importance and consequentiality of the incentive structure set by institutional arrangements that govern elite recruitment and candidacies for the type of aspirant coming forward (e.g., Black, 1972; Schlesinger, 1966; Seligman, 1964). In contrast to the dimension of the selectorate and the degree of centralization, the unifying effect of the candidacy dimension does not work through the (in-)dependency on party selectors for renomination felt by candidates but rather through its effect on the self-selection of committed personnel coming forward. Contributions in the edited volume on candidate selection by Gallagher and Marsh (1988) present cross-sectional information on candidacy criteria, but lack systematic research on the unifying consequences of variations on the candidacy dimension. Limited empirical research has shown that candidates selected through 
open recruitment following nationwide and formally undiscriminating calls for applications exhibit policy attitudes different from those of co-partisans that were selected through traditional channels (Smith \& Tsutsumi, 2014) and that these candidates are less active in parliament than those MPs with a stronger party membership background (Rehmert, 2017). As of now, the theoretical and empirical research on the candidacy dimension is bleak and empirical evidence on its effect on party unity is lacking completely.

In this study, I draw on the principal-agent framework to flesh out the reasoning of why parties may choose to set stricter Candidacy Eligibility Criteria (CEC), such as a minimum length of party membership or the collection of signatures, and present the first empirical investigation of the unifying effects of different types of CEC. My theoretical argument is that by imposing more demanding CEC, parties avoid the problem of adverse selection through screening aspirants for candidacy. By employing tougher screening mechanisms parties can uncover candidates' commitment to the party, as opportunists are likely to be deterred by demanding criteria while loyal aspirants can signal their commitment to the party by fulfilling the very same. Empirically, I make use of roll-call voting data from 16 countries, a unique and new data set with information on parties' CEC over time based on roughly 500 historical party constitutions as well as data from candidate surveys. In several regression models I show that those CEC that require aspirants to be a party member for a certain period of time before the candidacy and those CEC that nudge aspirants to maintain good relations and networks with other party members are correlated with higher voting unity in parliament at the party level and higher expressed loyalty in candidate surveys.

These findings speak to two arguments made in the literature. First, it relates to the argument of sorting of citizens with similar ideological proclivities into parties (e.g., Krehbiel, 1993; Willumsen, 2017), as CEC may serve as an amplifier for this behavior since opportunists looking for a quick way to national office may be deterred from joining the party when learning about demanding CEC. Second, this finding underscores the importance of socialization into party milieus and internalization of party rules and norms (e.g., Crowe, 1983, 1986). As Dodson (1990) has argued, group membership, in this case party membership, leads to the creation of group identity in the individual, entailing the development of psychological attachment and, in combination with regular contact with co-partisans, nudges the new member to reevaluate their own attitudes and behavior in light of what they deem essential to belong.

Hence, this study contributes to the literature on party unity and candidate selection by proposing insights into the empirical consequences of the candidacy dimension in CSM and by adding to our understanding of how 
parties' internal organizations affect party unity and therefore the working of parliaments. The next section lays out the theoretical framework and derives hypotheses to be tested following the elaboration of the research design and data.

\section{Theory}

Parties have to delegate actions at the micro-level to their candidates (e.g., campaign speeches) and MPs (e.g., voting behavior). As any delegation relationship, this one is prone to potential agency loss, too, when the candidate or MP (the agent) has preferences diverging from that of the party leadership (the principal). By delegating these actions, parties rely on their members not to undermine the unified image and the perception of the party it wishes to display to the electorate. Although a unified party image brings benefits to all its members - candidates, MPs, and party leaders alike - by sending a clear and unblurred policy signal to voters (e.g., Greene \& Haber, 2015), individual candidates and MPs may be tempted electorally to defect from the official party line to cater to particularistic constituency or interest group interests (e.g., Kiewiet \& McCubbins, 1991; Tavits, 2009; Willumsen \& Ohberg, 2017).

Parties interested in containing agency loss and in maintaining an undiluted policy image should thus be inclined to instill party unity by employing ex ante mechanisms, that is, mechanisms related to the selection of candidates that share the same preferences with the broader party, and ex post mechanisms, that is, those related to the monitoring and sanctioning of candidates' and MPs' behavior. Recent research has focused more heavily on parties' ex post mechanisms, by looking into when and how parties punish renegades at time of renomination (Schröder \& Manow, 2016) or how effective disciplining is in keeping the party united (e.g., Kam, 2009). In this article, I show empirically that ex ante screening mechanisms, too, are crucial in promoting party unity by way of producing a more loyal party personnel (see Müller, 2000). The next paragraphs lay out my theoretical reasoning and develops my main hypothesis.

\section{Adverse Selection in Candidate Recruitment}

At the nomination stage, parties are confronted with different types of candidates. Some candidates, hereafter referred to as opportunists, are motivated mainly by office, whereas others, loyalists, are motivated by policy. Naturally, parties favor loyalists over opportunist candidates as the former constitutes the party's main personnel in parliament (see Galasso \& Nannicini, 2011). 
The party's dilemma is that it can neither observe whether candidacyseekers are loyalists or opportunists nor their potential for undermining the party's cohesiveness at times. One way that parties could solve this problem of adverse selection is to employ screening mechanisms that make it more difficult for opportunist aspirants to persist (Kiewiet \& McCubbins, 1991; Lupia, 2003). This screening can come in the form of CEC, that is, requirements set forth in a party's constitution adjudicating whether a candidate is formally eligible to run or not. This not only ensures avoiding opportunist would-be candidates through deterrence but also creates a structure of selective incentives and rewards for loyalist and long-time activists (Hazan \& Rahat, 2010, p. 21).

First and foremost, by employing tougher CEC, parties can raise the cost of seeking candidacy for all types of candidates. These costs may accrue from the time and money to be invested but also from indispensable long-term networking efforts. The Belgian Socialist Party of the 1970s epitomizes the potentially high costs associated with the ambition for candidacy; aspirants were required to have joined the party, the Socialist trade union, and health insurance at least 5 years before seeking candidacy. Moreover, they were also asked to have joined the Socialist cooperate with minimum annual purchases and to have subscribed to the party's newspaper. Even their spouses and children were expected to join the respective organizations of the party and were not allowed to attend Catholic schools (see De Winter, 1988).

Strict requirements like these, although not always completely enforceable, serve two purposes that benefit party unity. First, highly demanding requirements, such as a certain period of prior party membership, are likely to deter opportunists who shun the effort to be invested for several months or years in the service of the party. Truly opportunist aspirants are rather attracted to political outlets that are less restrictive and in which nominations are comparably easier to obtain. However, in the case an opportunist would-be candidate has joined a party with strict CEC, nonetheless, they are forced to comply with the party's formal rules to be considered for nominations. This often entails the socialization into prevailing party norms and values with the likely result that their preferences have converged with that of the party at the time they have obtained eligibility. Still, in most instances, it is the ideological orientation of many would-be candidates that make them join parties in the first place. As the studies in van Haute and Gauja (2015) and by Young and Cross (2002) show, the major factor driving party membership is ideological conviction and not career advancement.

Second, strict requirements create an incentive structure of rewards for those who have already joined the party. Here, ambition for office can only unfold after years of service to the party, entailing processes of socialization 
into and internalization of common norms and values. The longer the time spent in a certain group, new entrants may be socialized into the groups values and norms through compliance and/or affiliative ties. Although ambitious new members have to play by the rules to be considered for nominations in parties that demand such strict CEC (compliance), an increase in psychological attachment to the party and contact with co-partisan nudges new members to reevaluate their own attitudes and behavior in light of what they deem essential to belong (affiliative ties) (Dodson, 1990). Parties that demand CEC that entail long-term membership or networking within the party are likely to impose these socializational processes on future candidates. And those aspirants for candidacy that formally fulfill the eligibility criteria send a strong signal to the selectorate. Moreover, the processes of socialization that many screening mechanisms try to encourage through their stipulations entail not necessarily a homogenization of policy preferences, but much more likely the internalization of party unity as a norm in and for itself, as suggested by survey data reported by Crowe $(1983,1986)$.

Granted, electoral considerations may weaken a party's preference for loyalists and instead urges them to select less loyal but electorally more attractive candidates. Some parties that have demanding formal screening mechanisms, indeed, allow for waivers for certain candidates that would otherwise not be eligible, given the approval of some higher ranking party committee. Candidates that receive these kind of waivers, however, are very likely to be in good standing with the respective party branch in charge and have proven their value to the party or they would not be under consideration in the first place. That is, even when looking for electorally more attractive candidates, party loyalty is likely to play a big role in the selection. These stipulations leave untouched the formal criteria that still unfold their effects on the majority of candidates. Moreover, as these sorts of waivers are mainly relevant for single-seat electoral districts, the large number of safe seats (see Matland \& Studlar, 2004) suggests that most opportunist candidates are, first of all, an exception - as they are not needed in safe districts - and, second, are likely to run in marginal seats that not all of them may win. Eventually, their number in any given electoral cycle should be small and not taint the theoretical logic or empirical test of the hypothesized relationship between CEC and candidate respective party behavior.

Thus, demanding strict CEC affect party unity and candidate loyalty through two channels: (a) deterrence of opportunists, that is, amplifying ideological sorting into political parties (e.g., Willumsen, 2017) and (b) selection of candidates that have been socialized into prevailing party norms and values (see Müller, 2000). Based on these two postulated channels, I expect that $\mathrm{CEC}$ that entail greater deterrence potential and an enforced socialization, 
namely party membership and in particular lengthy party membership as well as the network-intensive collection of signatures from co-partisans, are associated with greater party unity. CEC that lack this sort of enforced socialization, such as monetary deposits or pledges of loyalty, are less likely to deter or socialize ill-fitting candidates into the party's norms. Moreover, union membership and religious affiliation could either strengthen party unity through socioeconomic homogeneity or, given the additional principals such as labor unions or churches, weaken it (see Carey, 2007). Finally, the absence of formal CEC is expected to correlate negatively with party unity. In the empirical analysis, I will first explore the unifying effects of different types of screening mechanisms at the party level and, second, how different types of CEC affect the expressed loyalty of candidates toward their party's policy platform. Using two slightly different analyses at the individual level of the candidate, I explore whether CEC have rather a deterrence effect on potentially unloyal party members to-be or a socialization effect on ambitious members that have joined the party.

\section{Research Design}

\section{Data}

The data used to empirically assess my hypothesis on party unity stem from several sources. Data on parties' CEC come from the Political Party Database (PPDB) (Poguntke et al., 2016). ${ }^{1}$ Based on recent official party statutes and constitutions, parties' formal eligibility criteria for candidates are coded in a binary fashion for the following requirements: party membership, union membership, religious affiliation, pledge of loyalty, collection of signatures, and monetary deposits. The minimum length of party membership prior to candidacy is measured in months. These variables form my independent variables for the analyses below.

As CSM in many countries are subject only to the discretion of the party leadership or a qualified majority of party members at party conventions, CSM including CEC are comparably easy to reform. To explore changes over time, I have in addition to the PPDB data collected hundreds of historical party statutes for mainly social democratic parties from Australia, Belgium, Germany, Ireland, The Netherlands, New Zealand, Norway, Portugal, and the United Kingdom. ${ }^{2}$ Generally, we see a decline in such meritocratic requirements as minimum periods of party membership in these social democratic parties, as the Norwegian Labour Party exemplifies by demanding 3 months of prior membership from 1973 until 2002, when it has been reduced to 1 month. Many social democratic parties in fact have 
instituted formal requirements only in the 1970s. The decline over time can possibly be attributed partly to the dwindling away of traditional party milieus in the electorate in the wake of increasing individualism and declining unionized work as well as a decline in the importance of comparable organizations adjacent to the political realm (e.g., Dalton \& Wattenberg, 2002; van Biezen \& Poguntke, 2014).

I use two dependent variables that operate at different analytical levels. The first applies to the party-level and measures the party's unity in roll-call votes. I have collected data on roll-call votes for 16 countries from national sources. Where possible, I have done so for two legislative cycles to get variation on potential confounders such as government status and party size (see Sieberer, 2006). ${ }^{3}$ Voting unity is measured by the Agreement Index (AI) as proposed by Hix et al. $(2005)^{4}$, by party and legislative cycle.

As roll-call votes in many countries suffer from high selection bias (Hug, 2009) and are subject to party discipline instilled through other ways than mere preference homogeneity (Kam, 2009), I complete this measure by a second dependent variables from the Comparative Candidate Survey (CCS) that applies at the individual level. ${ }^{5}$ Candidates were asked anonymously whether MPs should follow their own opinion or their party position in case of conflict. I recoded their answers in a way that loyal answer behavior equals 1 and 0 otherwise.

By employing these two dependent variables, I can assess the importance of parties' CEC for such consequential actions as roll-call votes in parliament, but can also probe their impact on candidates' reverence for their party's position individually and thus establish a plausible link at the micro-level between CEC and voting unity.

As neither parties' CEC nor parties' voting behavior and candidates' attitudes unfold in an institutional vacuum, I control for several institutional confounders in my analyses. Apart from the government status and party size as mentioned already above, I also control for the centralization of the selectorate dimension in candidate selection (Hazan \& Rahat, 2010), to rule out possibly spurious relations between CEC and my dependent variables. The data for this variable come from the Democracy and Accountability Linkage Project (DALP). ${ }^{6}$ The variable's values range from 1 to 4 in real numbers capturing the level at which selection takes place. A 1 indicates national party leaders as deciding upon selection and a 4 indicates local actors to be in control. Values in between indicate regional levels to be in charge (2) or that selection is an outcome of bargaining between different levels (3). An additional control at the party level is the party's age, measured as the years between its foundation and the first year of the legislative cycle. I expect that older and more institutionalized parties tend to have higher CEC than newer parties. 
A second important control variable is the electoral system and its effect on candidates and MPs behavior. To measure the degree of centrifugal pressures candidates and MPs are exposed to, I control for the incentive of cultivating a personal vote of an electoral system. Data for this variable come from Johnson and Wallack (2012) who coded countries' electoral systems in accordance with Carey and Shugart's (1995) classification. Here, the maximum value of 10 indicates an electoral system that incentivizes the cultivation of the personal vote the strongest. Descriptive statistics for my two analyses can be found in Tables A1 to A4 in the Appendix.

\section{Candidacy Eligibility Criteria}

How do CEC distribute across different types of parties? Are there systematic differences in what certain types of parties demand from their candidates? Hazan and Rahat (2010) speculate that catch-all parties might be more lenient in their requirements due to electoral considerations, whereas more ideological parties put more emphasize on whom they recruit and run as candidate. In addition, Gallagher (1988) sees a difference in formal requirements between left-wing and right-wing parties, with the former one being more demanding. Table 1 presents a cross-sectional snapshot of the share of parties in the PPDB that have instituted a given criterium, grouped by their party family affiliation.

In contrast to Gallagher and to Hazan and Rahat, it is not the more ideological parties and not rather left-wing parties that demand the fulfillment of formal CEC. It seems that parties that follow one of the traditional ideologies of the 19th century, that is, Social Democracy, Liberalism, and Christian Democracy, as well as Conservatism, are the ones with higher numbers of formal candidacy requirements. Ecological and Green parties, as well as Agrarian ones tend to be more lenient in terms of formal requirements. However, CEC do not provide any information on possible informal criteria and screening mechanisms. In case of Green parties, though, this might possibly relate to these parties' self-image of openness and intraparty democracy.

\section{Data Analysis}

\section{CEC and Party Voting Unity}

In how far do CEC in fact have an impact on parties' behavior? Table 2 presents results from fractional logit models explaining voting unity in parliament. All models have been estimated with country and party-family 


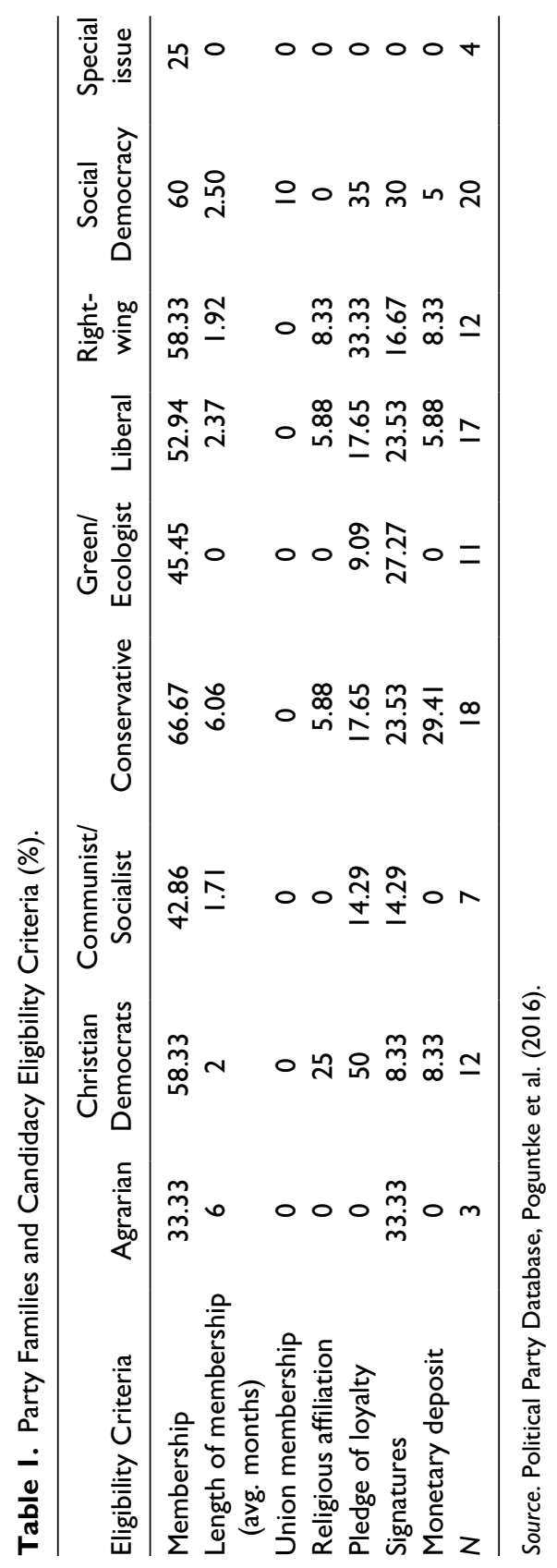




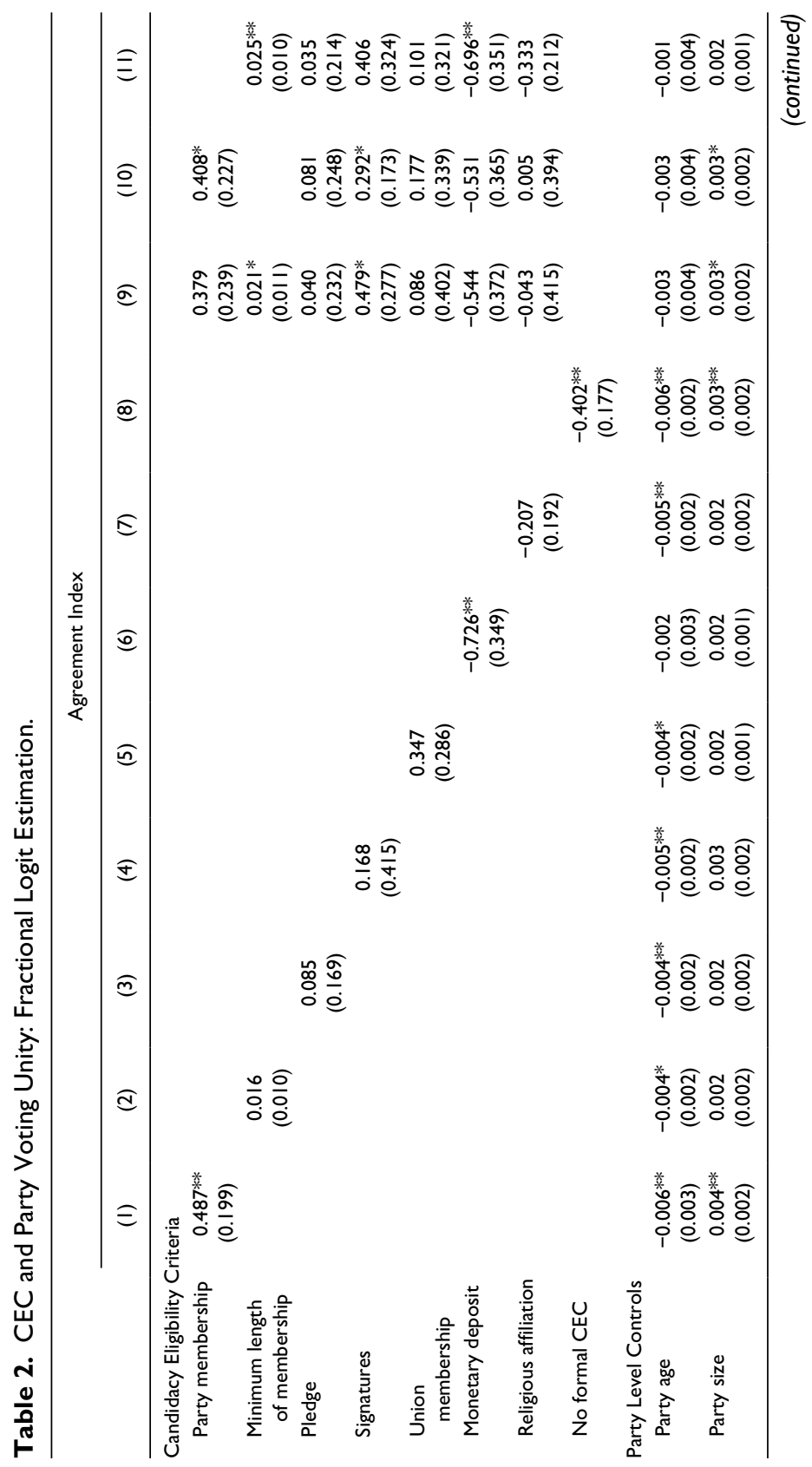




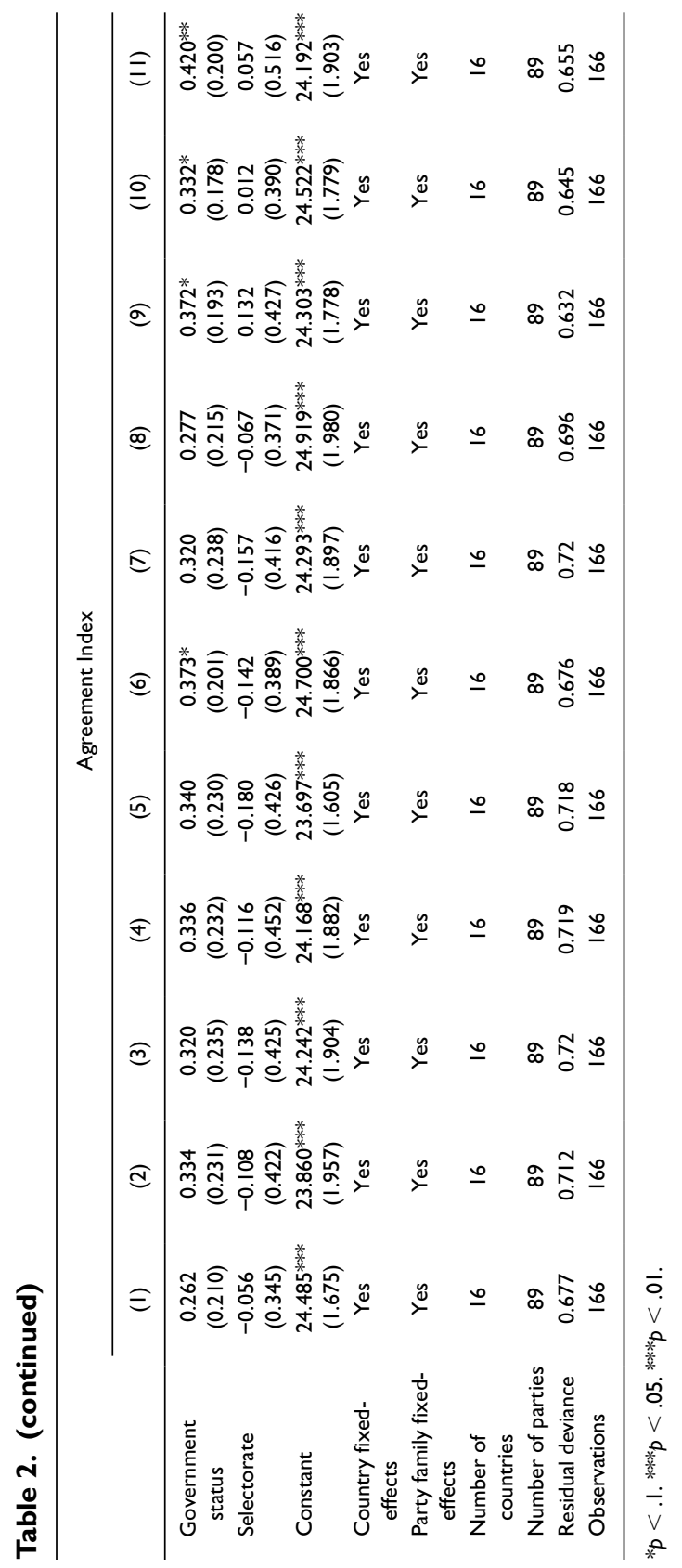


fixed-effects and coefficients are shown with standard errors clustered by country and party. Moreover, controls for a party's age, its size, its government status, and its degree of centralization in its selectorate are included. Country fixed-effects effectively control for influences emanating from the electoral system. The main independent variables, that is, the various types of $\mathrm{CEC}$, are once included individually and once collectively. ${ }^{7}$

In the models with individual CEC predictors, three specifications and their CEC stand out: (a) Parties requiring membership from their candidates tend to have higher agreement scores; (b) in contrast to this, parties asking only for a monetary deposit of its candidates, and (c) those parties that do not institute any sort of formal CEC appear to be less unified.

However, as parties may institute multiple criteria at the same time, model specifications including all predictors are shown as well. In these more fully specified models, formal criteria such as party membership, and especially a minimum length of membership or the collection of signatures from other party members in support of one's candidacy are all (though in parts only marginally) statistically associated with higher unity in parliamentary voting.

Interestingly, these three types of CEC found in favor of higher unity require candidates to immerse themselves deeply with the party through official (long-term) membership and/or the building of support networks within the party. This corresponds nicely with the notion that it is the affiliative ties and the social identity of a party member respective candidate and MP that comes with officially belonging to a certain group that informs their political behavior. Or, from the party's perspective, instituting these kind of criteria ensures the selection of those members that have engaged with the party and its members more seriously and who thus have signaled their commitment.

Figure 1 shows average marginal effects (AME) for all types of CEC. The quantities shown are the expected increases on the AI ranging from 0 to 100 . The AMEs of no formal CEC are obtained from Model (8) in Table 2, the others are obtained either from Model (10) or (11). Although the effects appear to be rather miniscule, the average of the AI across all parties in this sample is extremely high 98.7. Against this backdrop, the effect of a 0.512 increase when demanding official party membership pushes the expected unity score to 99.2 - almost perfect unity. In the same vein, the installment of monetary deposits for candidacies reduces unity to below 98, entailing a greater number of votes that see defections.

Government status, previously found to be consequential (e.g., Sieberer, 2006), appears to have effects on unity only in some specifications. The findings for the selectorate dimension are at odds with theoretical expectations and previous empirical research - though the overall direction of its effect is 


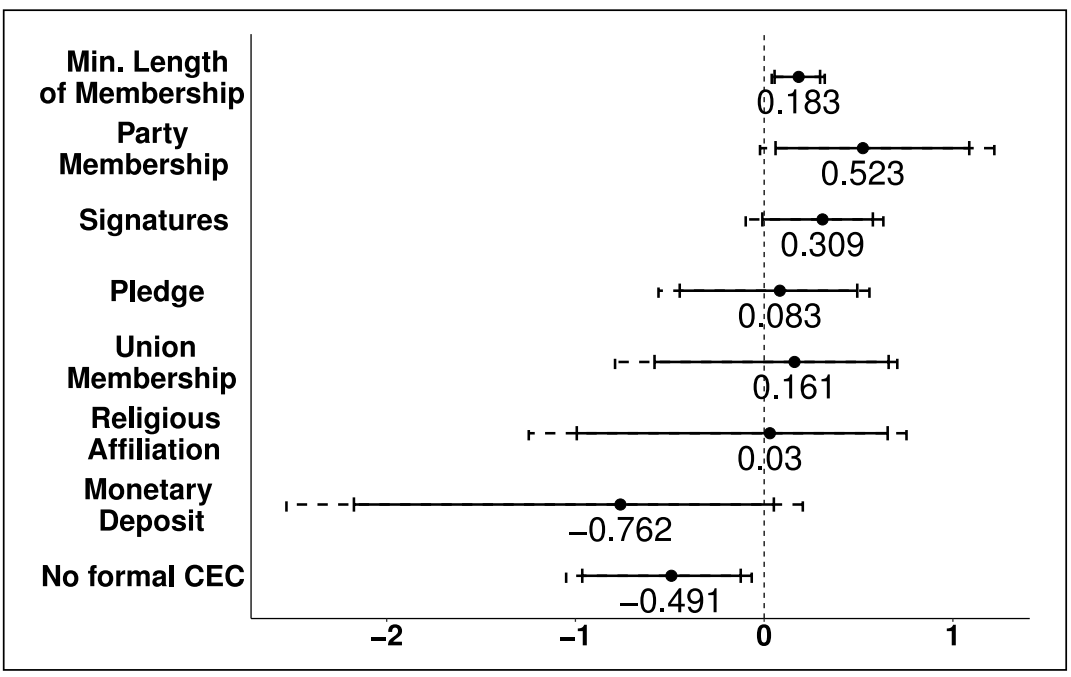

Figure I. Average marginal effects on voting unity by CEC.

Solid lines present $90 \%$ confidence intervals, dashed ones present $95 \%$ confidence intervals. Obtained from I,000 simulated random-draws from the variance-covariance matrix. Based on Models (8), (I0), and (II) from Table 2. AME of a unit-change except for length of membership for which AME is calculated for a change of I SD.

in line with expectations (e.g., Shomer, 2016, 2017). Party age exhibits a negative and party size a positive effect on voting unity. The latter finding is arguably somewhat counterintuitive, as the greater the number of MPs, the greater the risk of particularistic incentives to materialize.

To sum up, this explorative analysis of roll-call votes led to some interesting tentative findings that support the expectation that screening mechanisms and CEC that encourage the development of a social identity as a party member and also affiliative ties to other party members produce a more loyal pool of candidates to-be. However, although candidates of these parties have internalized party norms and very likely share many policy positions in the first place (see Crowe, 1983, 1986), parties that merely ask for a monetary deposit or that do not install any sort of formal eligibility criteria at all are found to be less unified - presumably through the selection of candidates that lack in reverence for the party's policies and image and in the internalization of prevailing party norms.

Although these findings speak to the importance of formal CEC in molding party behavior, one caveat to this analysis is the uniform coding of CEC that does not take into account possible changes in CEC over time. It could 
very well be that current MPs have joined their party under different CEC decades before. Nonetheless, most parties have seen a move toward less strict requirements over a time period most relevant for my sample. This implies that parties that are strict today are likely to have been even stricter in previous periods, suggesting an underestimation of the predictors' effects.

Ultimately, analyses relying on roll-call votes to gauge preference homogeneity or loyalty toward the party usually suffer from several shortcomings, such as a biased collection of actually recorded votes and the fact that most parties instill voting unity through "carrot-and-stick" discipline. Keeping this in mind, the next section will recover corresponding effects of these types of CEC at the individual level bar the uniform coding of CEC and placed in a setting in which candidates' behavior is less distorted by expectations of rewards or punishments by party whips when anonymously speaking their mind.

\section{CEC and Candidate Loyalty}

Although the previous analysis gauges the influence of CEC on unity and loyalty at the party level, this section examines the effect of different types of CEC at the individual level using data from candidate surveys to establish a plausible link between CEC and candidates' loyalty. Candidates were asked the question, "An MP in a conflict between own opinion and the party position should follow?" I recoded this variable in a way that a 1 indicates following one's own opinion and 0 following the party line. The first analysis examines whether and in how far eligibility criteria in place at the time the now-observed candidates have joined the party exert any impact on these candidates' expressed loyalty. This analysis, thus, tests whether CEC serve as a useful deterrence on opportunists and keeping them from joining the party. In other words, do demanding CEC amplify ideological sorting into political parties?

\section{CEC as Deterrence}

Table 3 reports logit estimates of the influence of CEC on candidates' loyalty to the party platform. The sample is restricted to social democratic parties from 10 countries for which I could establish their CEC over a longer period of time. ${ }^{8}$ Social democratic parties provide an intriguing class of parties to study changes in CEC as their traditional support milieus and supply of personnel, that is, organized labor, have undergone structural changes in the last decades. CEC in these parties, partly for these reasons, exhibit larger variation. ${ }^{9}$ An overview of these parties CEC are presented in Table A4 in 
Table 3. CEC at Time of Joining the Party and Candidate Loyalty: Logit Estimation.

Party position over own opinion
(
(2)
(3)

(4)

\begin{tabular}{|c|c|c|c|c|}
\hline \multicolumn{5}{|l|}{ Candidacy Eligibility Criteria } \\
\hline $\begin{array}{l}\text { Minimum length of } \\
\text { membership }\end{array}$ & $\begin{array}{l}0.022 * * * \\
(0.004)\end{array}$ & & & $\begin{array}{l}0.020 * * * \\
(0.004)\end{array}$ \\
\hline Pledge & & $\begin{array}{c}0.294 \\
(0.256)\end{array}$ & & $\begin{array}{l}0.141 \\
(0.212)\end{array}$ \\
\hline No formal CEC & & & $\begin{array}{l}0.195 \\
(0.901)\end{array}$ & \\
\hline \multicolumn{5}{|l|}{ Individual level controls } \\
\hline Ever employed by party & $\begin{array}{c}0.232 \\
(0.256)\end{array}$ & $\begin{array}{l}0.236 \\
(0.255)\end{array}$ & $\begin{array}{l}0.233 \\
(0.250)\end{array}$ & $\begin{array}{c}0.234 \\
(0.258)\end{array}$ \\
\hline Time party member (years) & $\begin{array}{c}0.009 \\
(0.008)\end{array}$ & $\begin{array}{c}0.009 \\
(0.009)\end{array}$ & $\begin{array}{l}0.004 \\
(0.009)\end{array}$ & $\begin{array}{l}0.010 \\
(0.009)\end{array}$ \\
\hline \multicolumn{5}{|l|}{ System level controls } \\
\hline Incentive for personal vote & $\begin{array}{l}-0.401 * * * \\
(0.075)\end{array}$ & $\begin{array}{c}-0.133 \\
(0.117)\end{array}$ & $\begin{array}{c}-0.258 * * * \\
(0.062)\end{array}$ & $\begin{array}{l}-0.326^{* * *} \\
(0.112)\end{array}$ \\
\hline Constant & $\begin{array}{l}3.588 * * * \\
(0.531)\end{array}$ & $\begin{array}{l}1.430 \\
(1.168)\end{array}$ & $\begin{array}{l}2.744 * * * \\
(0.468)\end{array}$ & $\begin{array}{l}2.873 * * * \\
(1.027)\end{array}$ \\
\hline Party fixed-effects & Yes & Yes & Yes & Yes \\
\hline Number of parties & 10 & 10 & 10 & 10 \\
\hline Observations & 639 & 639 & 639 & 639 \\
\hline Log likelihood & -358.490 & -359.121 & -359.373 & -358.429 \\
\hline Akaike information criterion & 742.980 & 744.242 & 744.746 & 744.858 \\
\hline
\end{tabular}

$\mathrm{CEC}=$ Candidacy Eligibility Criteria.

$* p<.1 . * * p<.05 . * * * p<.01$.

the Appendix. All models are estimated with party fixed-effects and standard errors clustered by party.

Through the focus on one single party family and the inclusion of party fixed-effects, I effectively compare the consequences for party loyalty when candidates join their party under different sets of CEC. Thus, coefficients present effects aggregated over parties of this party family. Furthermore, this allows me to estimate the effect of CEC on candidates' loyalty while controlling for parties' organizational and ideological make-up. To further account for potential cohort effects, I control at the individual level for the length of party membership. In addition, I include an indicator for having ever been employed by the party. ${ }^{10}$ These two variables account for heterogeneity 


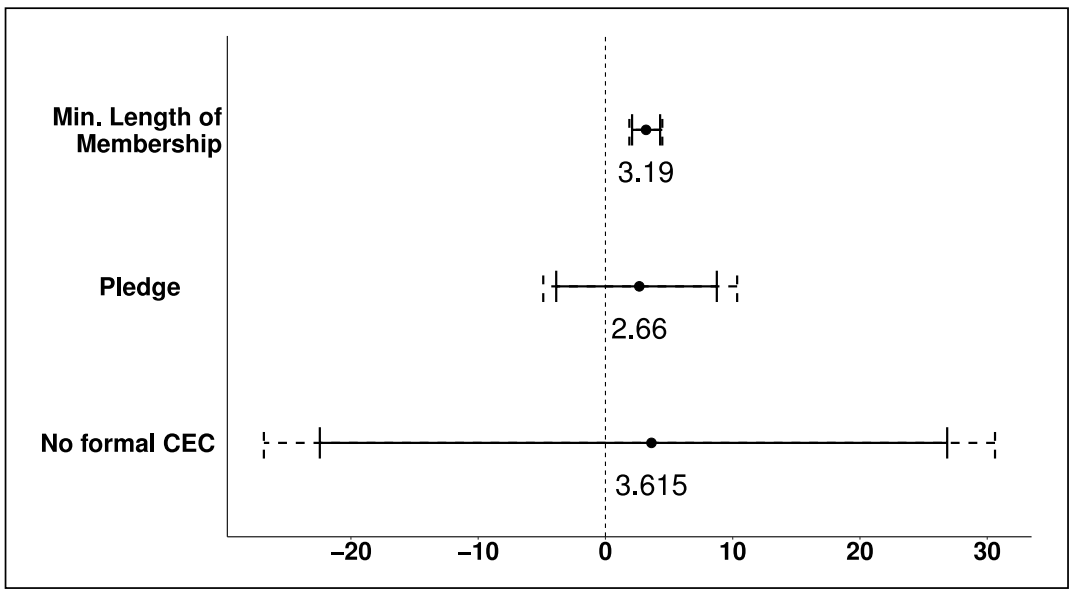

Figure 2. Average marginal effects on candidate loyalty by CEC.

Solid lines and whiskers present $90 \%$ confidence intervals, dashed ones present $95 \%$ confidence intervals. Obtained from I,000 simulated random-draws from the variancecovariance matrix. Based on Models (3) and (4) from Table 3. AME of a unit-change respective ISD change for minimum length of membership.

among candidates in terms of commitment to the party. Finally, a variable capturing the incentive of the electoral system to cultivate a personal vote is included to control for the centrifugal temptations candidates are exposed to. Given the low variation over time for most CEC, I have to focus on a comparison of differences in the demanded minimum length of party membership, the signing of a pledge of loyalty and no formal CEC.

Among the variables capturing the effects of eligibility criteria, only the minimum length of membership yields a significant effect with the expected direction of the effect. Candidates that have joined their party while it demanded a longer minimum period of membership express greater loyalty than candidates of parties demanding a shorter or no fixed periods of membership at the time of joining. Hence, this result speaks to the possible sorting and deterrent effects CEC may unfold upon potential new party members. Figure 2 presents average marginal effects of all three variables of interest. The average marginal effect of a $1 S D$ change, that is, about 6 months, in the minimum length of membership required before a candidacy can formally be obtained results in a 3.2\%-point decrease in following one's own opinion.

For the other two CEC variables variation is rather low, which, in combination with party fixed-effects, very likely explains the presented insignificant effects. ${ }^{11}$ In fact, only two parties in the sample changed their CEC as fundamentally as moving from no formal CEC to requiring membership. 


\section{CEC as Socialization}

In this final analysis, I examine the effects of CEC in place at the time of nomination. In this cross-sectional analysis, I remove candidates that have competed in the election prior to the one in the survey. In this way, I minimize the risk that previous candidates and especially incumbents who could have originally been selected under a different set of CEC and are now reselected automatically. That is, I look at new candidates and the effect of CEC in place at the time of their nomination on their expressed loyalty toward the party. However, due to this pruning of the data, I am left with only 37 parties from six countries.

As in previous analyses, I control for a set of potential confounders at the individual, party and country level. Besides country and party family fixedeffects, I control for the length of membership of individual candidates and whether they have ever been employed by the party. At the party level, I control for the centralization of the selectorate. Table 4 presents results from logit estimation with standard errors clustered by parties. Corresponding to the findings from my other two analyses, it is again the minimum length of membership and the collection of signatures that exhibit statistically significant effects in the expected direction. Candidates, nominated for the first time, are less likely to follow their own opinion in a conflict with their party's position and instead express greater loyalty to the party's policy platform, if their party demands a period of party membership and/or a collection of signatures before they become eligible for a candidacy. These types of CEC nudge or rather force candidates to undergo processes of socialization within the party to either become eligible after a certain period of time or establish networks within the party.

The results from Table 4 again are in line with my expectation: parties instituting screening mechanisms can expected their pool of candidates to be more loyal. Figure 3 shows average marginal effects of each type of CEC at the time of nomination of first-time candidates' expressed loyalty. A standard deviation change in the minimum length of membership reduces the probability of choosing one's own opinion over the party position by roughly $11 \%$. Demanding the collection of signatures, too, reduces the likelihood of going against the party by roughly $10 \%$. These results at the individual level complement the results from the first analysis and underscore the importance of candidacy eligibility criteria. Candidates of parties that institute no formal CEC are surprisingly not found to be significantly less loyal. It could be that parties without formal CEC employ tougher informal selection criteria as a substitute. The next section sums up the results, mentions some caveats of this analysis, and links the findings to the bigger picture of the current status of the literature. 


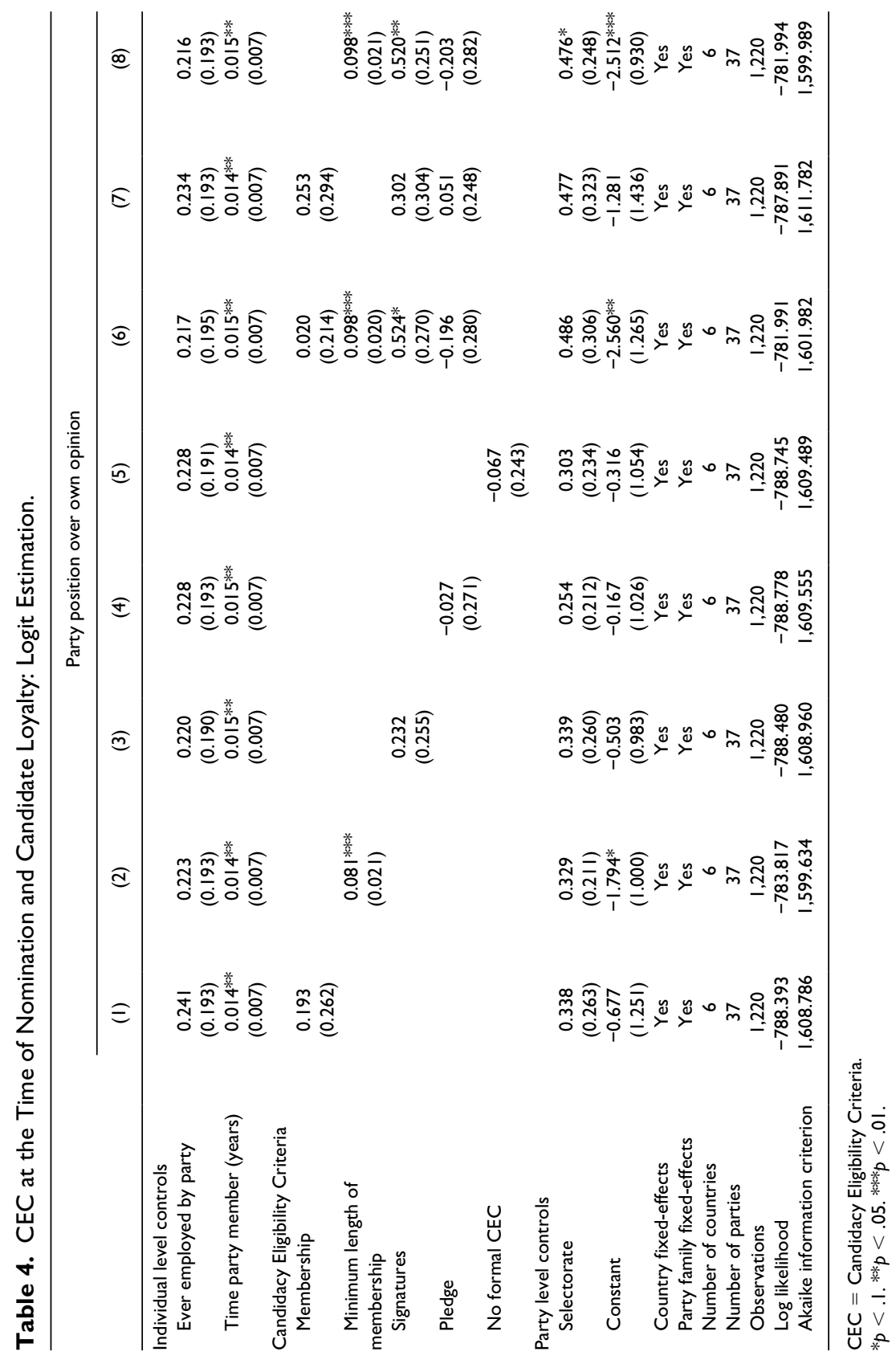




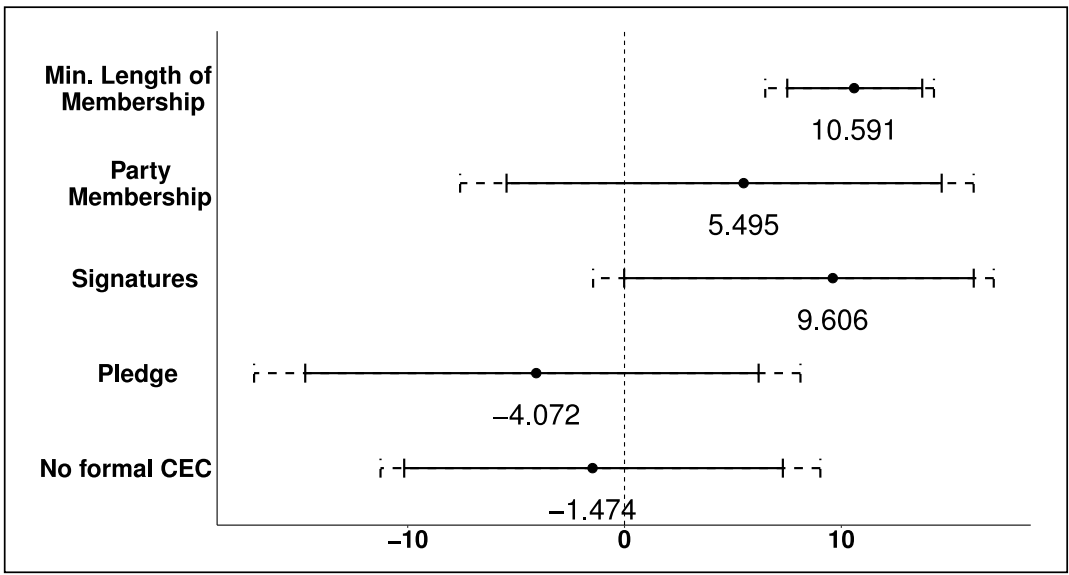

Figure 3. Average marginal effects on candidate loyalty by CEC.

Solid lines and whiskers present $90 \%$ confidence intervals, dashed ones present $95 \%$ confidence intervals. Obtained from I,000 simulated random-draws from the variancecovariance matrix. Based on Models (5), (7), and (8) from Table 4. AME of a unit-change respective ISD change for minimum length of membership.

\section{Conclusion}

CEC are highly consequential party rules that affect what type of candidate voters face in the voting booth. However, its consequences for party unity among others are underresearched. In contrast, the other dimensions of candidate selection as conceptualized by Hazan and Rahat (2010), namely the dimensions of the selectorate and of the centralization, have been receiving more and more attention in the last two decades. To remedy this imbalance, this article has argued and empirically tested that CEC can serve as a countermeasure to adverse selection in candidate recruitment and ensures the selection of candidates that are loyal to the party once elected. Especially those candidacy criteria that require and incentivize candidates to seriously immerse themselves with the party and its members turn out to be associated with higher party unity and candidate loyalty. The underlying factors contributing to this behavior are thought to be the psychological attachment and a social identity that evolve in the (enforced) socialization process and shape the attitudes and behavior of candidates and MP.

Even though these findings significantly advance our understanding of how CEC influence candidate and party behavior, they remain subject to some limitations. First, the analysis of parliamentary voting is restricted to a crosssectional comparison of whipped votes and the individual analyses are based 
on elite survey data, with which establishing causal links are difficult (see also Rüdig \& Sajuria, 2018). Second, parties' decisions to adopt, change, or scrap eligibility criteria altogether might be endogenous to strategic considerations in response to electoral incentives, intraparty struggles or ideological differentials in the supply of potential candidates. All this warrants further investigations. I have presented a longitudinal analysis to partially address both of these issues. However, low variation and lack of information on parties' CEC over a longer time span preclude a more thorough investigation at this point. A possible avenue for addressing this problem is a systematic data collection effort going back in time or exploiting within-party variation in, for instance, federal systems. Moreover, future research should also engage in disclosing the impact and methods of informal screening mechanisms of candidates, to add further scrutiny of the important topic of candidate selection - especially in light of gender imbalances among candidates.

In summary, the findings of this study suggest a new angle through which party unity and candidate selection can be looked at and calls for more attention to eligibility criteria in the study of party and political elite behavior in general. Studies on party unity or representation, for instance, stand to gain by taking into account the type of personnel constituting the party, or any social group for that matter, and its screening mechanisms for admission. For the study of candidate selection, eligibility criteria should be studied for its own sake, but also in light of possible conditional effects with other dimensions of candidate selection and possible conditional consequences for the nomination of members of minority groups.

\section{Appendix}

Table Al. Descriptive Statistics for Voting Unity Analysis.

\begin{tabular}{lccccc}
\hline Variable & $N$ & $M$ & \multicolumn{1}{c}{ SD } & Minimum & Maximum \\
\hline Agreement score & 166 & 0.988 & 0.014 & 0.935 & 1.000 \\
CEC membership & 166 & 0.596 & 0.492 & 0 & $\mathrm{I}$ \\
CEC length of membership & 166 & 2.895 & 5.810 & 0 & 36 \\
CEC signatures & 166 & 0.211 & 0.409 & 0 & $\mathrm{I}$ \\
CEC pledge & 166 & 0.253 & 0.436 & 0 & $\mathrm{I}$ \\
CEC union membership & 166 & 0.024 & 0.154 & 0 & $\mathrm{I}$ \\
CEC religious affiliation & 166 & 0.048 & 0.215 & 0 & $\mathrm{I}$ \\
CEC monetary deposit & 166 & 0.090 & 0.288 & 0 & $\mathrm{I}$ \\
No formal CEC & 166 & 0.325 & 0.470 & 0 & $\mathrm{I}$ \\
Party's age & 166 & 50.651 & 42.220 & 0 & I76 \\
\hline
\end{tabular}


Table AI. (continued)

\begin{tabular}{lcrrcc}
\hline Variable & $N$ & $M$ & \multicolumn{1}{c}{$S D$} & Minimum & Maximum \\
\hline Party size & 166 & 53.276 & 65.733 & 3 & 355 \\
Government status & 166 & 0.432 & 0.488 & 0 & 1 \\
Minority Government & 166 & 0.297 & 0.432 & 0 & 1 \\
Surplus Government & 166 & 0.228 & 0.397 & 0 & 1 \\
Coalition Government & 166 & 0.886 & 0.319 & 0 & 1 \\
Selectorate & 166 & 2.657 & 0.764 & 1.000 & 4.000 \\
\hline
\end{tabular}

$\mathrm{CEC}=$ Candidacy Eligibility Criteria

Table A2. Descriptive Statistics for Loyalty Analysis I.

\begin{tabular}{lcccccc}
\hline Variable & $N$ & $M$ & $S D$ & Minimum & Median & Maximum \\
\hline $\begin{array}{l}\text { Own opinion over party } \\
\quad \text { position }\end{array}$ & 639 & 0.490 & 0.500 & 0 & 0 & 1 \\
$\quad$ Ever employed by party & 639 & 0.121 & 0.326 & 0 & 0 & 1 \\
Time party member (years) & 639 & 18.676 & 11.545 & 0 & 18 & 48 \\
$\quad$ No formal CEC & 639 & 0.119 & 0.324 & 0 & 0 & 1 \\
$\begin{array}{l}\text { Pledge } \\
\text { Minimum length of }\end{array}$ & 639 & 0.362 & 0.481 & 0 & 0 & 1 \\
$\quad 639$ & 5.252 & 8.458 & 0 & 0 & 24 \\
$\quad$ membership & & & & & 10 & 10 \\
\hline
\end{tabular}

CEC $=$ Candidacy Eligibility Criteria.

Table A3. Descriptive Statistics for Loyalty Analysis II.

\begin{tabular}{lcccccc}
\hline Variable & $N$ & $M$ & \multicolumn{1}{c}{$S D$} & Minimum & Median & Maximum \\
\hline $\begin{array}{l}\text { Own opinion over party } \\
\text { position }\end{array}$ & 1.220 & 0.506 & 0.500 & 0 & $\mathrm{I}$ & $\mathrm{I}$ \\
$\begin{array}{l}\text { Ever employed by party } \\
\text { Time party member (years) }\end{array}$ & 1.220 & 0.113 & 0.317 & 0 & 0 & $\mathrm{I}$ \\
$\begin{array}{l}\text { Membership } \\
\text { Minimum length of }\end{array}$ & 1.220 & 0.625 & 10.775 & 0 & 9 & 53 \\
$\quad$ membership & 1.220 & 4.286 & 5.406 & 0 & 0 & 12 \\
Signatures & 1.220 & 0.189 & 0.392 & 0 & 0 & 1 \\
$\begin{array}{l}\text { Pledge } \\
\text { No formal CEC }\end{array}$ & 1.220 & 0.475 & 0.5 & 0 & 0 & 1 \\
Selectorate & 1.220 & 0.249 & 0.433 & 0 & 0 & 1 \\
\hline
\end{tabular}

$\mathrm{CEC}=$ Candidacy Eligibility Criteria. 
Table A4. Overview of Parties' CEC from Loyalty Analysis.

\begin{tabular}{|c|c|c|c|c|c|c|}
\hline \multirow[b]{2}{*}{ Country } & \multirow[b]{2}{*}{ Party } & \multirow[b]{2}{*}{$\begin{array}{c}\text { Time } \\
\text { coverage }\end{array}$} & \multicolumn{4}{|c|}{ Candidacy Eligibility Criteria } \\
\hline & & & Membership & $\begin{array}{l}\text { Length of } \\
\text { membership }\end{array}$ & Pledge & None \\
\hline Australia & ALP & $1983-2007$ & Yes & I2-24 months & Yes & No \\
\hline \multirow[t]{2}{*}{ Belgium } & PS & $1978-2006$ & Yes & - & Yes (1997-) & No \\
\hline & $\mathrm{SPa}$ & $2002-2010$ & No & - & Yes & No \\
\hline Denmark & Sd & 2008-2009 & Yes & 12 months & No & No \\
\hline Germany & SPD & $1962-2008$ & Yes (I97I-) & - & No & Yes $(-197 \mid)$ \\
\hline Ireland & Lab & $1974-2007$ & Yes & $6-12$ months & No & No \\
\hline Netherlands & PvdA & 1972-2006 & Yes & $0-2$ months & Yes & No \\
\hline New Zealand & LP & $|969-20| \mid$ & Yes & I2-24 months & No & No \\
\hline Norway & DNA & $1967-2007$ & Yes & I-3 months & No & No \\
\hline Portugal & PS & |974-20| | & No & - & No & Yes \\
\hline $\begin{array}{l}\text { United } \\
\text { Kingdom }\end{array}$ & Lab & $1962-2010$ & Yes & I2-24 months & No & No \\
\hline
\end{tabular}

Sources. Official party statutes; Political Party Database (Poguntke et al., 2016; Gallagher and Marsh, 1988; Galligan, 2003).

Data of empty cells interpolated when information before and after available. Data on ALP partly interpolated from regional party branches. CEC = Candidacy Eligibility Criteria.

\section{Declaration of Conflicting Interests}

The author declared no potential conflicts of interest with respect to the research, authorship, and/or publication of this article.

\section{Funding}

The author received no financial support for the research, authorship, and/or publication of this article.

\section{ORCID iD}

Jochen Rehmert iD https://orcid.org/0000-0003-1225-1512

\section{Supplemental Material}

Supplemental material for this article is available online at the CPS website http:// journals.sagepub.com/doi/suppl/10.1177/0010414019897700

\section{Notes}

1. Online: http://www.politicalpartydb.org/

2. The focus on social democratic parties is for the most part a function of data availability. The Friedrich-Ebert-Stiftung, a think-tank linked to the German social democrats, has archived a substantial number of (historical) party statutes 
from mainly social democratic parties from many advanced democracies. For no other party family could I retrieve a comparable amount of party statutes. Other sources besides the parties themselves include the Instituut voor Sociale Geschiedenis, the Rijksuniversiteit Groningen, and the Norwegian Labor Movement Archives and Library.

3. These countries and periods are as follows: Austria (2006-2008, 2008-2013), Australia (2010-2013, 2013-2016), Belgium (2007-2010, 2010-2014), Canada (2008-2011, 2011-2015), Denmark (2007-2011, 2011-2015), Germany (20092013, 2013-2017), Hungary (2006-2010, 2010-2014), Ireland (2007-2011, 2011-2016), Israel (2006-2009, 2009-2013), Italy (2006-2008, 2008-2013), The Netherlands (2006-2010, 2010-2012), Norway (2009-2013, 2013-2017), Spain (2011-2015), Sweden (2006-2010, 2010-2014), United Kingdom (20052010, 2010-2015). Data for the Netherlands come from the Dutch Parliamentary Behavior Dataset (Louwerse et al., 2017), and data on the United Kingdom from the Public Whip, http://www.publicwhip.org.uk/.

4. In contrast to the widely used RICE Score of Cohesion, the Agreement Index allows to take into account not only Yea and Nay votes but also the number abstentions:

$$
\text { Agreement Index }_{i}=\frac{\max \left\{Y_{i}, N_{i}, A_{i}\right\}-\frac{1}{2}\left[\left(Y_{i}+N_{i}+A_{i}\right)-\max \left\{Y_{i}, N_{i}, A_{i}\right\}\right]}{\left(Y_{i}+N_{i}+A_{i}\right)},
$$

where $Y$ denotes the number of yea, $N$ the number of nay, and $A$ the number of abstentions for the $i$ th vote.

5. Online: http://www.comparativecandidates.org/

6. Online: https://sites.duke.edu/democracylinkage/data/

7. Robustness checks including additional control variables such as the type of government, that is, coalition and majority status (see Bevan \& Greene, 2018), as well as the timing of the legislative cycle (Döring, 2003) are shown in Tables 10 and 11 in the Supplemental Appendix. Furthermore, Table 9 in the Supplemental Appendix uses CCS data and analyzes at the party level the variance in selfreported left-right placements across parties' slates of candidates as a function of CEC. In all robustness checks, the overall picture remains the same. Candidacy Eligibility Criteria (CEC) that entail or enforce socialization processes result in greater unity and lower ideological variation respectively, while the lack of formal CEC and CEC that could add an additional principle of loyalty to candidates are associated negatively with unity and positively with ideological variance.

8. These parties are the Australian Labor Party, the Socialist Party-Different and the Parti Socialist of Belgium, the Social Democratic Party of Denmark, the Social Democratic Party of Germany, the Irish Labor Party, the Partij van de Arbeid of the Netherlands, the New Zealand Labor Party, the Norwegian Labor Party, the Socialist Party of Portugal and the Labor Party of the United Kingdom. Data sources next to my own collection efforts include the Political Party Database (PPDB), contributions in Gallagher and Marsh (1988) and by Galligan (2003). 
9. Moreover, data collection for social democratic parties was easier than for other party families, as many social democratic parties or labor movements have established foundations that archive such historical documents.

10. The inclusion of the employment variable results in the drop-out of the Irish data, as the item was not asked in the Irish wave of the survey. Running the models with the Irish data leaving out this variable does not change the findings substantially.

11. In models without party fixed-effects, given in Table 12 in the Supplemental Appendix, no formal CEC become negatively significant.

\section{References}

Bevan, S., \& Greene, Z. (2018). Cross-national partisan effects on agenda stability. Journal of European Public Policy, 25(4), 586-605.

Black, G. S. (1972). A theory of political ambition: Career choices and the role of structural incentives. American Political Science Review, 66(1), 144-159.

Bowler, S., Farrell, D. M., \& Katz, R. S. (1999). Party cohesion, party discipline, and parliaments. In S. Bowler, D. M. Farrell, \& R. S. Katz (Eds.), Party discipline and parliamentary government (pp. 3-22). Ohio State University Press.

Carey, J., \& Shugart, M. (1995). Incentives to cultivate a personal vote: A rank ordering of electoral formulas. Electoral Studies, 14(4), 417-439.

Carey, J. M. (2007). Competing principals, political institutions, and party unity in legislative voting. American Journal of Political Science, 51(1), 92-107.

Carey, J. M. (2009). Legislative voting and accountability. Cambridge University Press.

Crowe, E. W. (1983). Consensus and structure in legislative norms: Party discipline in the House of Commons. Journal of Politics, 45, 487-510.

Crowe, E. W. (1986). The web of authority: Party loyalty and social control in the British House of Commons. Legislative Studies Quarterly, 11, 161-185.

Dalton, R. J., \& Wattenberg, M. P. (Eds.). (2002). Parties without partisans: Political change in advanced industrial democracies. Oxford University Press.

de Lange, S. L., \& Art, D. (2011). Fortuyn versus wilders: An agency-based approach to radical right party building. West European Politics, 34(6), 1229-1249.

Depauw, S., \& Martin, S. (2008). Legislative party discipline and cohesion in comparative perspective. In D. Giannetti \& K. Benoit (Eds.), Intra-party politics and coalition governments (pp. 103-120). Routledge.

De Winter, L. (1988). Belgium: Democracy or oligarchy. In M. Gallagher \& M. Marsh (Eds.), Candidate selection in comparative perspective: The secret garden of politics (pp. 20-46). Sage.

Dodson, D. L. (1990). Socialization of party activists: National convention delegates, 1972-81. American Journal of Political Science, 34(4), 1119-1141.

Döring, H. (2003). Party discipline and government imposition of restrictive rules. Journal of Legislative Studies, 9(4), 147-163.

Faas, T. (2003). To defect or not to defect? National, institutional and party group pressures on MEPs and their consequences for party group cohesion in the European parliament. European Journal of Political Research, 42, 841-866. 
Galasso, V., \& Nannicini, T. (2011). Competing on good politicians. American Political Science Review, 105(1), 79-99.

Gallagher, M. (1988). Conclusion. In M. Gallagher \& M. Marsh (Eds.), Candidate selection in comparative perspective: The secret garden of politics (pp. 236-283). Sage.

Gallagher, M., \& Marsh, M. (Eds.). (1988). Candidate selection in comparative perspective: The secret garden of politics. Sage.

Galligan, Y. (2003). Candidate Selection: More democratic or more centrally controlled? In M. Gallagher, M. Marsh, \& P. Mitchell (Eds.), How Ireland voted 2002 (pp. 37-56). Palgrave Macmillan.

Greene, Z. D., \& Haber, M. (2015). The consequences of appearing divided: An analysis of party evaluations and vote choice. Electoral Studies, 37, 15-27.

Hazan, R. Y., \& Rahat, G. (2010). Democracy within parties: Candidate selection methods and their political consequences. Oxford University Press.

Hix, S. (2004). Electoral institutions and legislative behavior: Explaining voting defection in the European parliament. World Politics, 56(2), 194-223.

Hix, S., Noury, A., \& Roland, G. (2005). Power to the parties: Cohesion and competition in the European parliament, 1979-2011. British Journal of Political Science, $35,209-234$.

Hug, S. (2009). Selection effects in roll call votes. British Journal of Political Science, 40, 225-235.

Johnson, J. W., \& Wallack, J. S. (2012). Electoral systems and the personal vote. https://dataverse.harvard.edu/dataset.xhtml?persistentId=hdl:1902.1/17901; http://hdl.handle.net/1902.1/17901

Kam, C. J. (2009). Party discipline and parliamentary politics. Cambridge University Press.

Kiewiet, R. D., \& McCubbins, M. D. (1991). The logic of delegation: Congressional parties and the appropriations process. The University of Chicago Press.

Krehbiel, K. (1993). Where's the party. British Journal of Political Science, 23(2), 235-266.

Louwerse, T., Otjes, S., \& van Vonno, C. M. C. (2017). Dutch parliamentary voting dataset. https://dataverse.harvard.edu/dataverse/dutchparl

Lupia, A. (2003). Delegation and its perils. In K. Strøm, W. C. Müller, \& T. Bergman (Eds.), Delegation and accountability in parliamentary democracies (pp. 33-54). Oxford University Press.

Matland, R. E., \& Studlar, D. T. (2004). Determinants of legislative turnover: A crossnational analysis. British Journal of Political Science, 34, 87-108.

Müller, W. C. (2000). Political parties in parliamentary democracies: Making delegation and accountability work. European Journal of Political Research, 37, 309-333.

Poguntke, T., Scarrow, S. E., Webb, P. D., Allern, E. H., Aylott, N., van Biezen, I., Calossi, E., Costa Lobo, M., Cross, W. P., Deschouwer, K., Enyedi, Z., Fabre, E., Farrell, D. M., Gauja, A., Pizzimenti, E., Kopecký, P., Koole, R., Müller, W. C., Kosiara-Pedersen, K., Rahat, G., . . .Verge, T. (2016). Party rules, party resources and the politics of parliamentary democracies: How parties organize in the 21st century. Party Politics, 22(6), 661-678. 
Rahat, G., \& Hazan, R. Y. (2001). Candidate selection methods: An analytical framework. Party Politics, 7(3), 297-322.

Rehmert, J. (2017, June 22-24). Behavioral consequences of open candidate recruitment [Paper presented]. Paper Presented at the 7th Annual General Conference of the European Political Science Association, Milan, Italy.

Rüdig, W., \& Sajuria, J. (2018). Green party members and grass-roots 56 democracy: A comparative analysis. Party Politics. https://journals.sagepub.com/doi/ abs/10.1177/1354068818754600

Schlesinger, J. A. (1966). Ambition and politics: Political careers in the United States. Rand McNally.

Schröder, V., \& Manow, P. (2016). Too clever by half? Low-threshold closed-list proportional representation and party split in Weimar Germany, 1919-1930 (CES Open Forum Series 27). https://ces.fas.harvard.edu/publications/too-clever-byhalf-low-threshold-closed-list-proportional-representation-and-party-split-inweimar-germany-1919-1930

Seligman, L. G. (1964). Elite recruitment and political development. Journal of Politics, 26(3), 612-626.

Shomer, Y. (2016). The electoral environment and legislator dissent. Comparative Politics, 48(4), 557-578.

Shomer, Y. (2017). The conditional effect of electoral systems and intraparty candidate selection processes on parties' behavior. Legislative Studies Quarterly, 42(1), 63-96.

Sieberer, U. (2006). Party unity in parliamentary democracies: A comparative analysis. Journal of Legislative Studies, 12(2), 150-178.

Smith, D. M., \& Tsutsumi, H. (2014). Candidate selection methods and policy cohesion in parties: The impact of open recruitment in Japan. Party Politics, 22(3), 339-353.

Tavits, M. (2009). The making of mavericks: Local loyalties and party defection. Comparative Political Studies, 42(6), 793-815.

van Biezen, I., \& Poguntke, T. (2014). The decline of membership-based politics. Party Politics, 20(2), 205-216.

van Haute, E., \& Gauja, A. (Eds.). (2015). Party members and activists. Routledge.

Willumsen, D. M. (2017). The acceptance of party unity in parliamentary democracies. Oxford University Press.

Willumsen, D. M., \& Ohberg, P. (2017). Toe the line, break the whip: Explaining floor dissent in parliamentary democracies. West European Politics, 40, 688-716.

Young, L., \& Cross, W. (2002). Incentives to membership in Canadian political parties. Political Research Quarterly, 55(3), 547-569.

\section{Author Biography}

Jochen Rehmert is a postdoctoral researcher at the Humboldt-Universität zu Berlin. His core interests are candidate selection, coalition politics and electoral redistricting. He received his $\mathrm{PhD}$ from the Hertie School of Governance in Berlin, Germany. 